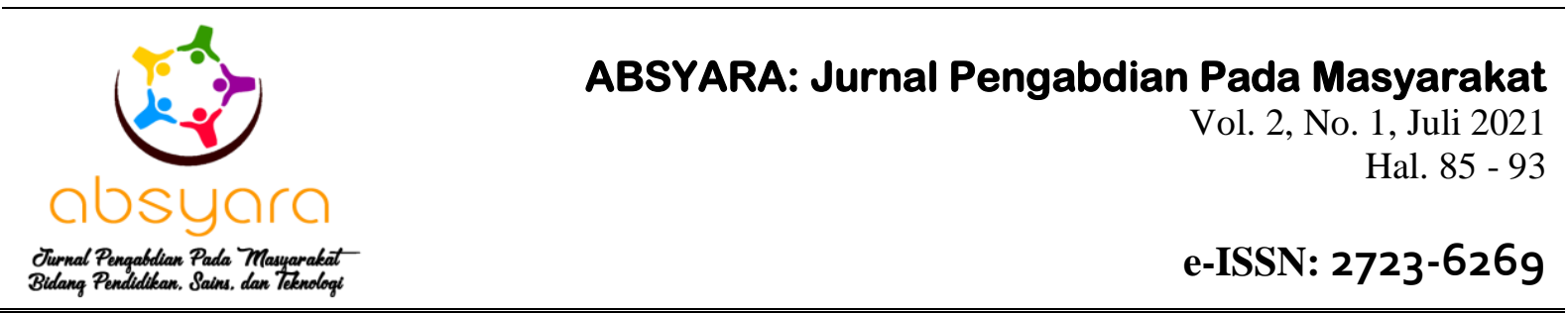

\title{
Pelatihan Penyusunan Ice Breaking untuk Penguatan Kompetensi Calon Guru
}

\author{
Asfi Aniuranti*1, M. Happy Nur Tsani ${ }^{2}$, Yasinta Wulandari ${ }^{3}$ \\ a.aniuranti@unupurwokerto.ac.id ${ }^{* 1}$ \\ 1,2,3 Pendidikan Bahasa Inggris, Universitas Nahdlatul Ulama Purwokerto
}

Received: 31 Mei 2021

DOI: 10.29408/ab.v2i1.3578
Accepted: 13 Juli $2021 \quad$ Online Published: 31 Juli 2021

URL: http://dx.doi.org/10.29408/ab.v2i1.3578

\begin{abstract}
Abstrak: Dalam setiap proses pembelajaran termasuk pembelajaran bahasa Inggris, terdapat sebuah tahapan yang disebut dengan ice breaking. Kegiatan yang secara umum hanya berlangsung beberapa menit tersebut adalah aspek yang penting. Setiap guru bahasa Inggris atau bahkan calon guru bahasa Inggris harus memiliki kemampuan dalam mempersiapkan ice breaking yang efektif. Meskipun dinilai sebagai tahapan pembelajaran yang penting, banyak mahasiswa calon guru yang melewatkan tahapan ini ketika mereka diminta untuk melakukan praktik mengajar. Oleh karena itu, tim PKM menilai bahwa pelatihan mengenai ice breaking masih sangat diperlukan oleh mahasiswa sebagai calon guru. Pelatihan ini sendiri diselenggarakan secara online selama dua hari melalui Google Meet, dan peserta pelatihan adalah para mahasiswa Program Studi Pendidikan Bahasa Inggris, Universitas Nahdlatul Ulama Purwokerto. Dalam kegiatan tersebut, para peserta belajar mengenai teoriteori yang terkait dengan ice breaking dan contoh-contoh ice breaking. Mereka juga melakukan beberapa praktik dalam menyusun ice breaking. Secara keseluruhan, pelatihan selama dua hari tersebut berlangsung dengan lancar. Hasil dari angket yang diberikan kepada para peserta juga cenderung positif, dan berdasarkan tugas yang dikumpulkan, kemampuan peserta dalam menyusun ice breaker juga cukup baik.
\end{abstract}

Kata Kunci: English as Foreign Language (EFL); Ice Breaking; Pelatihan Online

Abstract: In every teaching and learning process includes English teaching, there is a phase called ice breaking. The activity that generally only lasts a few minutes is a paramount aspect. Every English teacher or even the candidate has to be skillful in preparing effective ice breaking. Although ice breaking is viewed as a crucial stage in a teaching process, many students miss this phase when they have to do teaching practice. Therefore, the community service team regarding a workshop about icebreaking is still needed by the students as the teacher candidates. This workshop was conducted online via Google Meet in two days, and the participants were the students of the English Language Teaching Department of Universitas Nahdlatul Ulama Purwokerto. In the workshop, the participants learned the theories related to icebreaking and the examples of ice breaking. They also did some practice on creating ice breaking. Overall, the two-day workshop ran well. The questioner's result also tends to be positive, and based on the tasks submitted, the participant's ability to create ice breakers is good enough.

Keyword: English as Foreign Language (EFL); Ice Breaking; Online Workshop 


\section{PENDAHULUAN}

Paradigma pembelajaran termasuk pembelajaran bahasa Inggris telah mengalami pergeseran dari teacher-cantered learning ke student-cantered learning. Dalam studentcantered learning, pusat dari kegiatan pembelajaran adalah siswa dimana setiap guru berkewajiban mendorong siswa untuk berperan aktif dalam setiap kegiatan pembelajaran. Larasati (2018) menyatakan bahwa student-cantered learning menempatkan siswa sebagai fokus dari proses pembelajaran. Emaliana (2017) menambahkan bahwa student-cantered learning adalah tempat dimana para guru mempertimbangkan kebutuhan pembelajar secara individu maupun kelompok dan mendorong mereka untuk selalu berpartisipasi.

Meskipun pusat pembelajaran adalah siswa, setiap guru tetaplah memegang peranan penting dalam proses pembelajaran. Choudhury (2011) menyebutkan bahwa perubahan yang terjadi tidak mengurangi pentingnya pernanan guru dalam proses pembelajaran. Suwartono \& Aniuranti (2018) menambahkan bahwa guru dengan segala upaya dan peranannya sebagai direktur, manager, konselor, dan model dalam penggunaan bahasa yang mereka ajarkan, memfasilitasi pembelajaran di dalam kelas dan jika memungkinkan diperluas di luar kelas. Archana \& Rani (2017) juga menjelaskan bahwa guru memiliki berbagai peranan dalam proses pembelajaran seperti menjadi pembelajar, fasilitator, asesor, manager dan pengevaluasi. Dengan peranan yang penting dan beragam, tentu setiap guru diharuskan untuk merancang setiap aktivitas pembelajaran dengan matang dan penuh pertimbangan.

Setiap aktivitas pembelajaran mulai dari kegiatan awal, inti sampai akhir merupakan komponen penting yang menentukan tercapai tidaknya tujuan pembelajaran yang telah dirumuskan. Pada bagian awal pembelajaran terdapat kegiatan yang biasa dikenal dengan istilah ice breaking. Menurut Solihat, dkk. (2020) istilah ice breaker berasal dari dua kata bahasa asing, yaitu ice yang berarti es yang bersifat kaku, dingin, dan keras, sementara breaker berarti pemecah. Secara literal ice breaker dapat diartikan sebagai pemecah es. Dengan demikian dapat disimpulkan bahwa ice breaker merupakan upaya untuk memecahkan atau mencairkan suasanya yang dingin seperti es sehingga pembelajaran dapat berlangsung dengan lebih nyaman dan menyenangkan. Sementara itu Panggua (2016) mengungkapkan bahwa ice breaker dapat diartikan sebagai pemecah es dimana es disini merujuk pada banyak kondisi atau situasi. Singkatnya, dalam sebuah proses pembelajaran, ice breaker dapat diartikan sebagai sebuah usaha untuk memecahkan ketegangan selama proses pembelajaran sehingga suasana menjadi lebih kondusif dan menyenangkan.

Adanya ice breaking pada awal proses pembelajaran dinilai sebagai tahapan pembelajaran yang sangat penting. Yeganehpour \& Takkaç (2016) menyebutkan bahwa pada proses pembelajaran, ice breaking merupakan hal yang penting sebab mampu mendukung keberhasilan siswa dalam berbagai level berbeda. Kegiatan ice breaking sendiri umumnya dilaksanakan di awal pembelajaran. Menurut Marneni, dkk. (2017), menit-menit awal dalam kelas bahasa Inggris sangatlah penting sebab merupakan sebuah penataan yang menentukan bagaimana suasana secara keseluruhan nantinya, sehingga sangat penting untuk memulai dengan susuatu yang berkesan. Solihat, dkk. (2020) menambahkan bahwa ice breaking adalah sebuah aktivitas yang dapat digunakan untuk memecah ketegangan dan kejenuhan siswa dalam pembelajaran sehingga kelas menjadi menyenangkan dan lebih kondusif sebelum memasuki kegiatan utama. Hal ini penting karena suasana pembelajaran yang menyenangkan akan sangat 
berpengaruh terhadap sikap siswa dalam belajar. Seperti dinyatakan oleh Dryden \& Vos dalam Panggua (2016), bahwa pembelajaran akan lebih efektif jika dilaksanakan secara menyenangkan.

Forbes-Greene dalam Yeganehpour (2017) sendiri mengelompokkan ice-breaker menjadi tiga jenis, yaitu;

1. Pembuka (opener)

Ice-breaker ini dilakukan dengan cara memberikan tantangan dan memotivasi siswa. Opener ini dapat digunakan untuk memulai sesi pembelajaran atau diskusi dan dapat juga digunakan untuk mengenalkan topik baru.

2. Peningkat energi (energizer)

Peningkat energi atau energizer digunakan pada saat siswa mulai merasakan tekanan, terlalu santai atau kegiatan siswa terlihat stagnan dan datar.

3. Umpan balik dan pengungkapan (Feedback and disclosure)

Jenis ini digunakan lebih untuk tujuan komunikasi daripada hubungan interpersonal antar siswa.

Penggunaan berbagai jenis ice breaking sendiri dianjurkan untuk memperhatikan berbagai prinsip penerapan. Menurut Witkowski dalam Farwati, dkk (2019) terdapat beberapa prinsip penerapan ice breaking di dalam kelas, yaitu sebagai berikut ini:

1. Tujuan pembelajaran (Penggunaan ice breaking harus sesuai dengan tujuan pembelajaran.)

2. Pembelajar (Ice breaking yang digunakan disesuaikan dengan usia serta kemampuan para peserta didik.)

3. Managemen waktu (Penerapan ice breaking umumnya memakan waktu yang singkat, yaitu sekitar 20 menit.)

4. Pengendalian (Penggunaan ice breaking harus dikendalikan dengan baik sebab ice breaking umunya merupakan kegiatan yang singkat serta menyenangkan untuk menghidupakan dan membuat suasana kelas yang tidak menegangkan.)

Berdasarkan penjelasan di atas dapat disimpulkan bahwa kegiatan ice breaking di dalam proses pembelajaran dapat membawa dampak positif dalam upaya pencapaian tujuan pembelajaran, sehingga pemahaman mengenai kegiatan ice breaking merupakan hal yang penting untuk dikuasai oleh guru bahkan calon guru sekalipun. Akan tetapi, berdasarkan pengalaman tim, banyak mahasiswa di Prodi Pendidikan Bahasa Inggris, Universitas Nahdlatul Ulama Purwokerto mengalami kesulitan untuk melaksanakan kegiatan ice breaking. Hal ini dapat dilihat ketika mereka mengikuti kuliah micro teaching dimana mereka diharuskan untuk melaksanakan praktik mengajar. Sebagian besar dari mereka melewatkan kegiatan ice breaking. Kegiatan opening umumnya hanya dilakukan dengan menanyakan kabar, mengecek kehadiran, dan melakukan ulasan terhadap materi sebelumnya. Secara umum, sebagian besar dari mahasiswa langsung menuju ke kegiatan inti, yaitu pemberian materi pembelajaran yang baru.

Dengan mempertimbangkan kondisi tersebut, tim PKM menilai bahwa kegiatan pelatihan mengenai ice breaking sebagai salah satu upaya untuk memberikan pembekalan kepada mahasiswa sebagai calon guru merupakan hal yang penting untuk dilaksanakan. Melalui kegiatan tersebut, mahasiswa diharapkan mampu memahami konsep dasar ice breaking dan mampu menyusun berbagai ice breaking yang memungkinkan untuk diterapkan ketika melaksanakan proses pembelajaran. Secara pragmatis pelatihan memiliki hasil atau 
dampak yang positif baik bagi peserta maupun pelaksana pelatihan (individu atau organisasi) (Fauzi, dkk., 2020)

\section{METODE PELAKSANAAN}

\section{Waktu dan Lokasi}

Kegiatan PKM berupa pelatihan ini diikuti oleh para mahasiswa Program Studi Pendidikan Bahasa Inggris selama dua hari, yaitu pada tanggal 7 dan 8 November 2020. Kegiatan ini berlangsung secara daring melalui Google Meet.

\section{Prosedur pelaksanaan}

Metode yang digunakan dalam pengabdian masyarakat berbentuk rangkaian kegiatan berkesinambungan selama dua hari kerja. Kegiatan hari pertama dan kedua berlangsung dari pukul 07-00-12.00. Berdasarkan analisis terhadap kondisi dan situasi yang dibutuhkan mahasiswa, maka ditetapkan metode atau bentuk pelaksanaan kegiatan seperti yang diberikan dalam tabel berikut ini:

Tabel 1. Metode pelatihan

\begin{tabular}{clll}
\hline No & \multicolumn{1}{c}{ Bentuk Kegiatan } & \multicolumn{1}{c}{ Metode Pelaksanaan } \\
\hline 1. & $\begin{array}{l}\text { Penjelasan mengenai definisi, manfaat } \\
\text { dan cara menyusun ice breaking }\end{array}$ & Pemaparan materi, diskusi \\
2. & $\begin{array}{l}\text { Penggunaan ice breaking dalam } \\
\text { pembelajaran }\end{array}$ & Pemaparan materi dan demonstrasi \\
3. & $\begin{array}{l}\text { Praktik menyusun ice breaking dan } \\
\text { penggunaannya didalam pembelajaran }\end{array}$ & $\begin{array}{l}\text { Diskusi kelompok, presentasi dan } \\
\text { demonstrasi }\end{array}$ \\
\hline
\end{tabular}

Untuk dapat mengukur keberhasilan PKM, peserta diminta untuk membuat ice breaking secara individu dan dikirimkan melalui link Google Drive yang telah disiapkan. Setelah pelatihan sebagai bentuk evaluasi kegiatan, peserta juga diminta mengisi angket melalui platform Google Form sebagai penentu keberhasilan kegiatan. Secara umum angket tersbut terdiri dari dua bagian. Pertama, penilaian secara umum dari peserta mengenai kegiatan PKM. Kedua, pandangan mengenai ice breaking dalam konteks pembelajaran bahasa Inggris

\section{HASIL DAN PEMBAHASAN HASIL}

Pelatihan penyusunan ice breaking bagi mahasiswa sebagai calon guru bahasa Inggris berlangsung selama dua hari melalui Google Meet. Hari pertama diisi dengan pembekalan mengenai teori-teori yang terkait dengan ice breaking, yaitu definisi ice breaking, pentingnya ice breaking, cara penyusunan ice breaking serta berbagai contoh ice breaking yang berfokus pada empat keterampilan dalam bahasa Inggris, yaitu membaca, menulis, mendengarkan dan berbicara.

Pelatihan hari pertama diisi oleh dua orang, yaitu Asfi Aniuranti dan Yasinta Wulandari. Pengenalan dan pemberian contoh ice breaking untuk keterampilan mendengarkan dan berbicara disampaikan oleh Asfi Aniuranti. Teori-teori yang relevan dengan ice breaking dalam proses pengajaran bahasa Inggris disampaiakan sebagai pembekalan awal bagi para 
peserta. Dengan pembekalan tersebut, peserta akan semakin memahami konsep-konsep yang terkait dengan ice breaking. Berikut foto kegiatan sesi pertama.

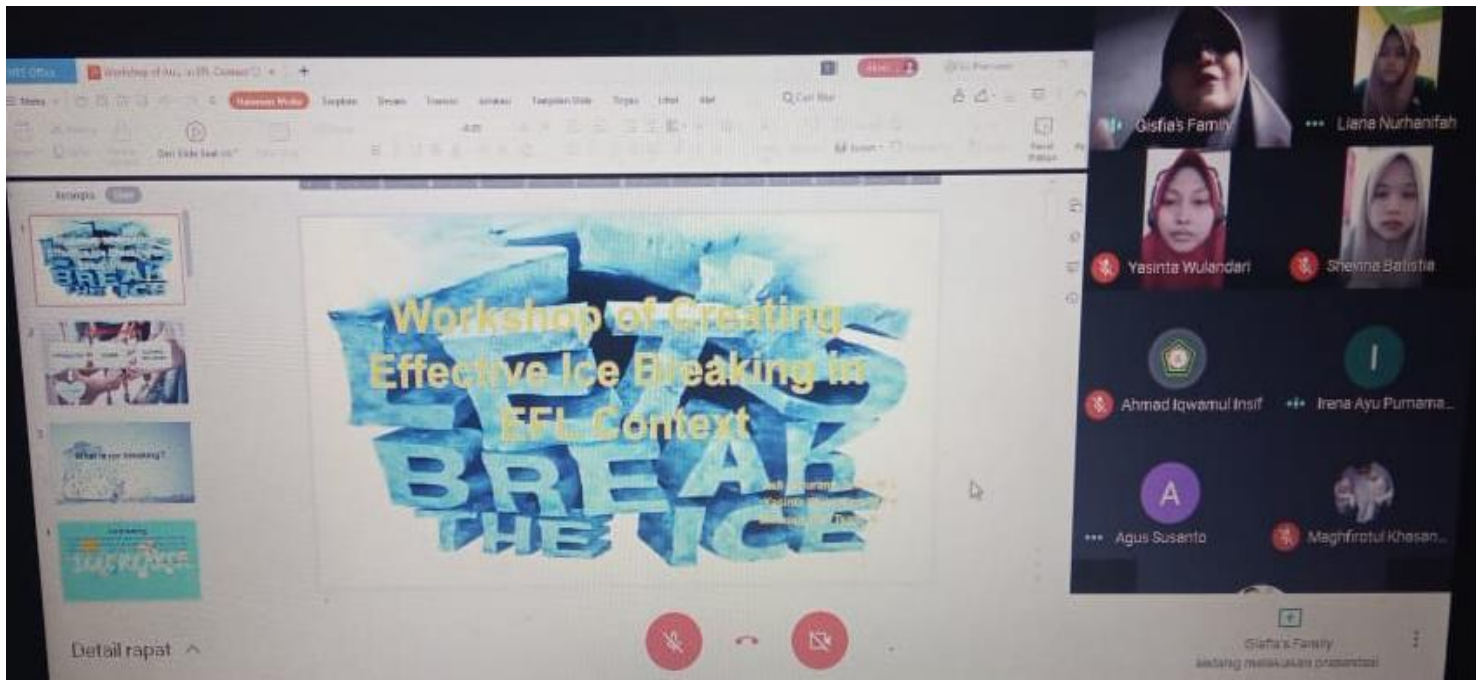

Gambar 1. Penjelasan mengenai teori-teori yang relevan dengan ice breaking

Setelah sesi pertama selesai, kegiatan dilanjutkan dengan sesi kedua yang diisi oleh Yasinta Wulandari. Proses pelatihan diteruskan dengan pemberian contoh ice breaking yang berfokus pada keterampilan membaca dan menulis. Sama halnya dengan contoh ice breaking sebelumnya, pemberian contoh juga didasarkan pada silabus yang berlaku saat ini. Berikut beberapa foto kegiatan.
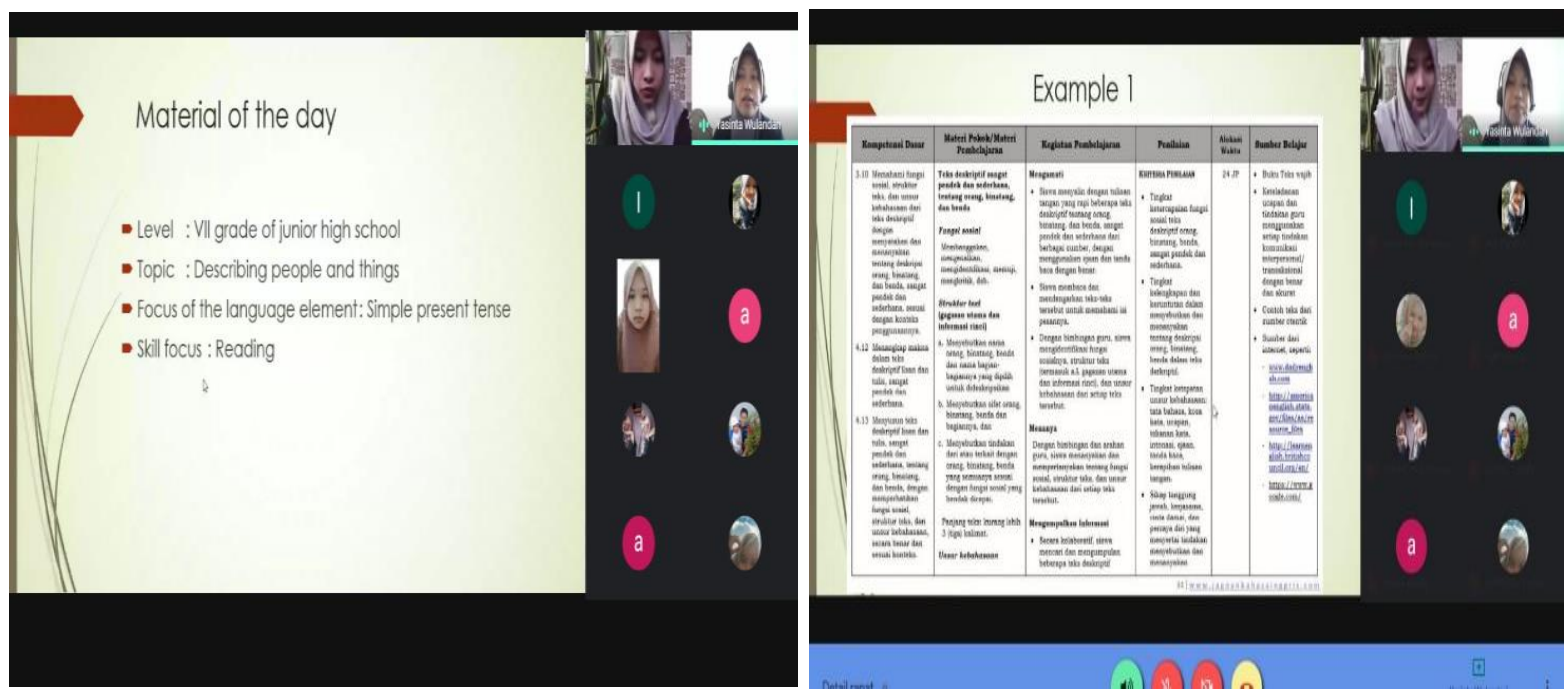

Gambar 2. Pemberian contoh ice breaking yang berfokus pada keterampilan membaca dan menulis

Setelah peserta mendapatkan pembekalan mengenai teori yang relevan dan contohcontoh ice breaking dalam konteks pembelajaran bahasa Inggris, peserta diberi kesempatan untuk mempraktikan proses penyusunan ice breaking di hari kedua. Pelatihan di hari kedua didampingi oleh M. Happy Nur Tsani. Berikut ini foto kegiatan hari kedua. 


\section{Practice Makes Perfect}

\begin{tabular}{|c|c|c|c|}
\hline Group 1 & Group 2 & Group 3 & Group 4 \\
\hline Topic : Recount Text & Topic : Procedure Text & Topic : Narrative Text & Topic : Report Text \\
\hline Grade : IN SMP & Grade: IN SMP & Grade: IX SMP & Grade: IX SMP \\
\hline Skill : Writing & Skill : Speaking & Skill : Listening & Skill : Reading \\
\hline Group 5 & Group 6 & Group 7 & Group 8 \\
\hline Topic : Making Captions & Topic : Offering Help & Topic : Motivating Songs & Topic : News Item Text \\
\hline Grade : XII SMA & Grade : XII SMA & Grade : XII SMA & Grade : XII SMA \\
\hline Skill : Writing & Skill : Speaking & Skill :Listening & Skill : Reading \\
\hline
\end{tabular}

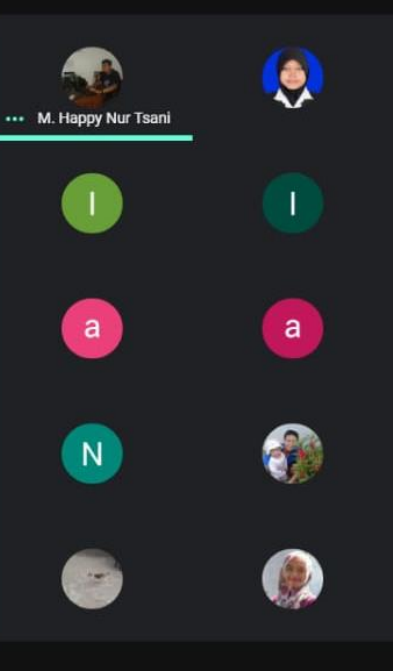

Gambar 3. Praktik terbimbing penyususnan ice breaking

Setelah parktik terbimbing selesai, peserta diberi kesempatan untuk melakukan praktik bebas dimana setiap peserta diminta untuk menyusun ice breaking dengan topik dan level yang dipilih sendiri oleh peserta. Peserta kemudian diminta untuk mengumpulkan hasil pekerjaan mereka ke link Google Drive. Berikut ini merupakan salah satu contoh hasil ice breaking yang berhasil disusun oleh salah satu peserta pelatihan.
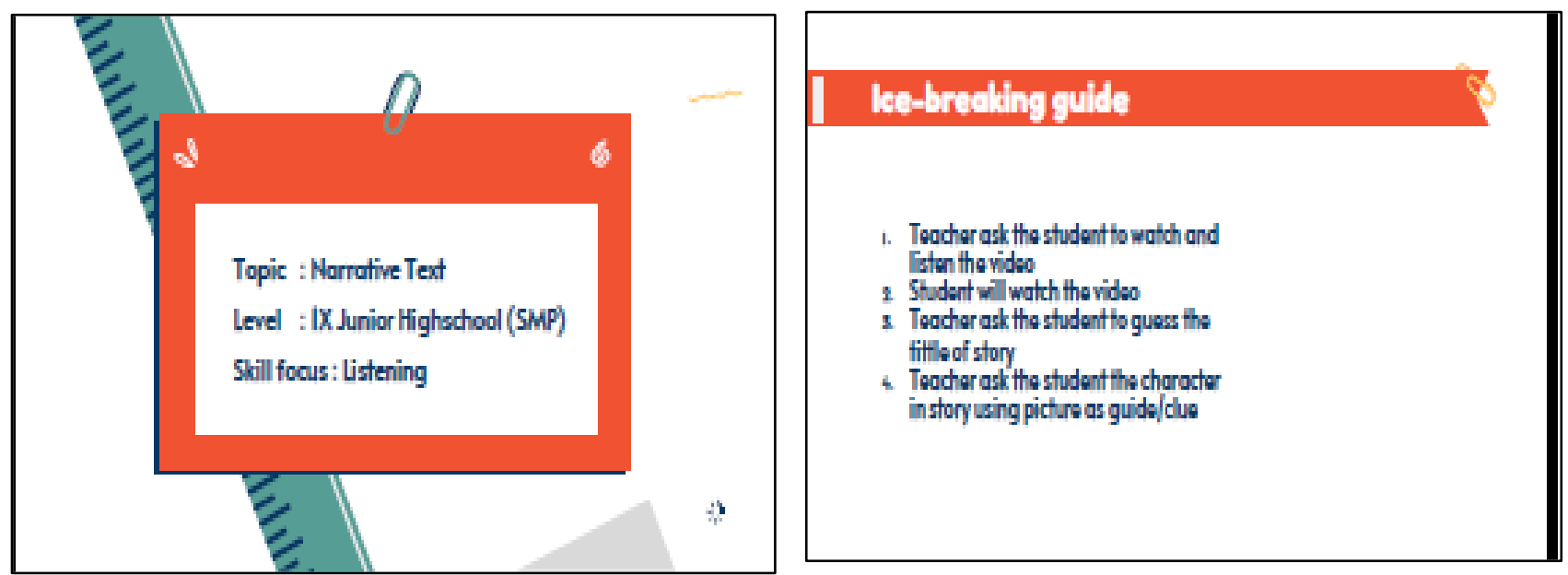

Gambar 4. Contoh ice breaking yang disusun peserta

Setelah seluruh peserta menyusun ice breaking yang diminta dan mengumpulkan ke link google drive, peserta diminta untuk mengisi angket mengenai kegiatan pelatihan yang telah dilaksanakan. Angket yang digunakan merupakan jenis angket tertutup yang terdiri dari delapan item dengan lima pilihan, yaitu Sangat Setuju (SS), Setuju (S), Netral (N), Tidak Setuju (TS), dan Sangat Tidak Setuju (STS). Angket tersebut dapat dibagi kedalam dua bagian, yaitu pendapat mahasiswa mengenai kegiatan pelatihan dan pendapat mahasiswa mengenai ice breaking dalam proses pembelajaran bahasa Inggris sebagai bahasa asing. Berikut rincian hasil angket yang telah diisi oleh peserta pelatihan. 
Tabel 2. Persepsi umum mengenai kegiatan pelatihan

\begin{tabular}{lcccccc}
\hline \multicolumn{1}{c}{ Pertanyaan } & SS & S & N & TS & STS \\
\hline $\begin{array}{l}\text { Pengenalan mengenai ice breaking yang } \\
\text { diberikan dapat dipahami }\end{array}$ & $45.5 \%$ & $36.4 \%$ & $9.1 \%$ & $9.1 \%$ & \\
$\begin{array}{l}\text { Contoh-contoh ice breaking yang diberikan } \\
\text { mudah untuk diaplikasikan }\end{array}$ & $27.3 \%$ & $72.7 \%$ & & & \\
\begin{tabular}{l} 
Kegiatan praktik yang diberikan membantu \\
\hline
\end{tabular} & $36.4 \%$ & $54.5 \%$ & $9.1 \%$ & & \\
\hline
\end{tabular}

Dari tabel di atas, dapat ditarik kesimpulan bahwa respon peserta pelatihan cenderung positif terhadap rangkaian kegiatan yang berlangsung selama dua hari. Persentase tertinggi masih berada pada bagian tanggapan positif, yaitu sangat setuju dan setuju. Tiga tahapan kegiatan selama pelatihan mendapat respon yang cenderung positif.

Tabel 3. Persepsi mengenai ice breaking dalam konteks pembelajaran bahasa Inggris

\begin{tabular}{lccccc}
\hline \multicolumn{1}{c}{ Pertanyaan } & SS & S & N & TS & STS \\
\hline $\begin{array}{l}\text { Ice breaking dibutuhkan dalam kelas } \\
\text { pembelajaran bahasa Inggris sebagai bahasa }\end{array}$ & & & & \\
asing & & & & \\
$\begin{array}{l}\text { Ice breaking membantu untuk menarik perhatian } \\
\text { siswa }\end{array}$ & $54.5 \%$ & $45.5 \%$ & & \\
$\begin{array}{l}\text { Ice breaking membantu guru untuk } \\
\text { mempersiapkan pembelajaran }\end{array}$ & $63.6 \%$ & $36.4 \%$ & \\
menyenangkan dan kondusif yang & & & \\
$\begin{array}{l}\text { Ice breaking adalah elemen yang penting dalam } \\
\text { kelas bahasa Inggris sebagai bahasa asing }\end{array}$ & $36.4 \%$ & $54.5 \%$ & $9.1 \%$ & \\
$\begin{array}{l}\text { Setiap guru butuh untuk mempersiapakan ice } \\
\text { breaking }\end{array}$ & $36.4 \%$ & $54.5 \%$ & $9.1 \%$ & \\
\hline
\end{tabular}

Lima item dalam angket yang menggali pendapat peserta mengenai ice breaking dalam proses pembelajaran bahasa Inggris juga mendapatkan tanggapan yang positif. Setiap item mendapatkan respon dengan persentase tertinggi di bagian sangat setuju dan setuju.

\section{PEMBAHASAN}

Semua contoh kegiatan ice breaking yang diberikan dikaitkan dengan silabus SMP, SMA sampai SMK sederajat. Hal ini dilakukan agar apa yang disampaikan relevan dengan kurikulum saat ini, yaitu kurikulum 2013 (K-13). Selain itu, mahasiswa sebagai calon guru dapat memahami bagimana seharusnya guru sebagai fasilitator pembelajaran menyusun atau mempersiapkan ice breaking yang merupakan bagian penting bagi setiap proses pembelajaran.

Kegiatan parktik penyusunan dibagi kedalam dua jenis, yaitu praktik terbimbing dan praktik bebas. Pada praktik terbimbing, peserta dibagi kedalam kelompok-kelompok untuk menyusun ice breaking untuk topik dan level tertentu. Setelah peserta berdiskusi, beberapa perwakilan diminta untuk memaparkan hasil diskusi mereka. Selama proses diskusi peserta tampak antusias dalam menyampaikan ide atau gagasan mereka mengenai bentuk-bentuk ice breaking yang mungkin digunakan. 
Persepsi umum dari peserta mengenai kegiatan ini menunjukkan persepsi yang positif. Sedangkan persepsi peserta mengenai ice breaking dapat disimpulkan bahwa ice breaking merupakan salah satu komponen penting yang dibutuhkan dalam proses pembelajaran dimana guru diharuskan untuk mempersiapkan hal tersebut secara matang. Hal ini senada dengan yang diungkapkan oleh Marneni, dkk. (2017). Mereka menjelaskan bahwa bahwa menit-menit pertama dalam kelas adalah hal yang sangat penting untuk mengatur seuasana secara keseluruhan sehingga sangatlah penting untuk memulai kelas dengan sesuatu yang berkesan. Selain itu, ice breaking juga dinilai dapat digunakan untuk menciptakan pembelajaran yang menyenangkan dan kondusif. Pendapat peserta yang tercermin dari hasil angket tersebut selaras dengan beberapa pendapat mengenai ice breaking. Pendapat tersebut selaras dengan apa yang diungkapkan Solihat, dkk. (2020). Mereka menyebutkan bahwa ice breaking adalah sebuah kegiatan yang dapat digunakan untuk memecahkan ketegangan dan kejenuhan para siswa dalam belajar sehingga kelas menjadi menyenangkan dan lebih kondusif sebelum memasuki kegiatan utama.

\section{SIMPULAN}

Pelaksanaan agenda PKM dalam bentuk pelatihan penyusunan ice breaking bagi mahasiswa Pendidikan Bahasa Inggris sebagai para calon guru telah berhasil dan tercapai output kegiatan dalam bentuk hasil karya peserta berupa contoh ice breaking yang dikumpulkan pada link Google Drive. Semua peserta telah memiliki pengetahuan dan pemahaman dalam menyusun dan menyiapkan ice breaking dalam pembelajaran. Melalui kegiatan pelatihan ini, peserta memiliki bekal untuk bisa menyiapkan ice breaking dalam setiap pembelajaran. Dengan demikian, kemampuan baru yang diperoleh dari pelatihan ini dapat mendukung kompetensi mahasiwa sebagai calon guru.

\section{PERNYATAAN PENULIS}

Artikel ini merupakan hasil karya sendiri yang belum pernah dipublikasikan baik secara keseluruhan maupun sebahagian, dalam bentuk jurnal, working paper atau bentuk lain yang dipublikasikan secara umum. Karya ilmiah ini sepenuhnya merupakan karya intelektual dan seluruh sumber yang menjadi rujukan dalam karya ilmiah ini telah sebutkan sesuai kaidah akademik yang berlaku umum, termasuk para pihak yang telah memberikan kontribusi pemikiran pada isi, kecuali yang menyangkut ekspresi kalimat dan disain penulisan.

\section{DAFTAR PUSTAKA}

Archana, S., \& Usha Rani, K. (2017). Role of a teacher in English language teaching (ELT). International Journal of Educational Science and Research (IJESR), 7(1), 1-4.

Choudhury, A. S. (2011). Classroom roles of English language teachers: The traditional and the innovative. Contemporary Online Language Education Journal, 1(1), 33-40.

Emaliana, I. (2017). Teacher-centered or student-centered learning approach to promote learning?. Jurnal Sosial Humaniora (JSH), 10(2), 59-70.

Farwati, D. Z., Rahmah, M., \& Sutisna, E. (2018). The application of Ice Breaking activities in teaching english to junior high school students. JETLi| Journal of English Language Teaching and Linguistics Studies, 1(1), 16-26. 
Fauzi, L. M., Supiyati, S., \& Rasidi, A. (2020). Workshop Distance Learning di masa Pandemic Covid 19. ABSYARA: Jurnal Pengabdian Pada Masyarakat, 1(1), 16-21.

Larasati, F. (2018). Student centered learning: an approach to develop speaking skill in EFL classroom. English Community Journal, 2(1), 153-157.

Marneni, S., Kumar, B.S., \& Bhukya, N. (2017). The role of Ice Breakers in English language classroom. International Journal of English Language, Literature in Humanities, 5(11), 457-463.

Panggua, S. (2016). The Effectiveness of Ice-Breaker activity to improve students' speaking skill of The Third Semester Students of English Department Students of FKIP UKI Toraja. Teaching English as a Foreign Language Overseas Journal, 2(1), 179-193.

Solihat, A., Astuti, A. R., \& Satriani, I. (2020). The influence of Ice Breaker to students'motivation in teaching english. Project (Professional Journal Of English Education), 3(2), 210-216. http://dx.doi.org/10.22460/project.v3i2.p210-216.

Suwartono, T., \& Aniuranti, A. (2018). Digital teaching tools in $21^{\text {st }}$ Century EFL classroom: Are our teachers ready?. ELLITE: Journal of English Language, Literature, and Teaching, 3(2), 57-62.

Yeganehpour, P. (2017). Ice-Breaking as a useful teaching policy for both genders. Journal of Education and Practice, 8(22), 137-142.

Yeganehpour, P., \& Takkaç, M. (2016). Using Ice-Breakers in improving every factor which considered in testing learners speaking ability. International Journal on New Trends in Education and Their Implications, 7(1), 58-68. 